

RESEARCH ARTICLE

\title{
SCREENING OF RESISTANCE SOURCE AGAINST SPOT BLOTCH DISEASE CAUSED BY BIPOLARIS SOROKINIANA IN TRITICUM AESTIVUM L.
}

\author{
Ashish Ojha ${ }^{1, *}$, Gyanendra Singh ${ }^{2}$, Bhudev Singh Tyagi ${ }^{2}$, Virender Singh, ${ }^{1}$ Rajita $^{1}$ and Pradeep Kumar ${ }^{1}$. \\ 1. Senior Research Fellow, Indian Institute of Wheat and Barley Research, Karnal-132001 (Haryana), India. \\ 2. Principal Scientist, Indian Institute of Wheat \& Barley Research, Karnal-132 001 (Haryana), India.
}

\section{Manuscript Info}



\section{Manuscript History}

Received: 15 November 2016

Final Accepted: 17 December 2016

Published: January 2017

Key words:-

Screening, Spot blotch, Germplasm,

Disease, wheat

\section{Abstract}

One hundred spring wheat genotypes/ germplasm (Triticum aestivum L.) lines related to Indian, CIMMYT, and Chinese were evaluated for spot blotch tolerance against natural epiphytotic conditions, caused by Bipolaris sorokiniana at hot spot locations Coochbehar, Kalyani and Karnal (Polyhouse), India Out of 100 screened entries 20 number of genotype showed Highly resistant or Immune to the disease, where as 28 genotype were resistant, 22 genotypes moderately resistant, 15 moderately susceptible and 15 genotypes susceptible. Indian germplasm lines tended to be more susceptible compression to lines originated from CIMMYT and China. Chirya-1, chirya-3, chirya-7, Yangmai\#6 and Mayoor, HRLSN lines from CIMMYT and LBRL lines from India showed high degree of resistance to the disease both under field and polyhouse conditions. On the basis of the disease severity under artificial epiphytotic polyhouse conditions, 20 promising lines were find highly resistant in field natural conditions for their genetic analysis \& potential for spot blotch breeding. These lines can be used hybridization programmes and since they have different parental background, it will help in diversification of gene pool. Some of these also have better potential for high yield and adaptation.

Copy Right, IJAR, 2016,. All rights reserved.

\section{Introduction:-}

Wheat (Triticum aestivum L.) is the largest grown and second prominent produced cereal crops worldwide after maize (Zea mays L.) with 697.9 million tones every year (Velu and Singh, 2013). Global food production might be increase at least $70 \%$ by 2050 when global population may likely to reach 9 billion. In India, wheat production and productivity was 95.6 million tonnes respectively, in 2013-14 which reveal decline tend to comparison year. with previous years Several biotic and biotic stresses such as spot blotch, rust, terminal heat stress and drought stress have adverse impact on wheat productivity in eastern regions of south Asia especially in the eastern gangetic plains of India (Joshi et al., 2007) It's a challenge for us, increasing production and productivity, enhanced level of multiple disease resistance in future genotypes will be very essential. Spot blotch, which is caused by the hemibiotrophic fungal pathogen Bipolaris sorokiniana (Sacc.) Shoem sun. Drechslera sorokiniana (Sacc) Subrm and jain (syn. Helminthosprorium sativum, telomprph Cochliobolus sativus), (Chowdhary et al., 2013), has emerged as a major production constraint in the eastern part of India and south Asia's intensive cropping system (Chatrath et al., 2007; Joshi et al., 2007a). Green revolution played a key role in ensuring food security in this population dense 
region of the world, which mainly comprises of India, Pakistan, Nepal and Bangladesh. Yield losses are significant, and depend on genotype, time of occurrence and severity of the disease, Sowing time, location and stress conditions. Saari (1998) reported that the average yield losses due to leaf blight in the Indian sub continanent were as much as $17.5 \%$. They are estimated to average $15-20 \%$ but can be reach 40 to $70 \%$ in susceptible genotypes. Satvinder et al., (2002) observed the yield losses ranged from 27\% to 56.6\% during 1998-99 in north eastern and north western plains of India, losses were estimated up to $15 \%$ on several farms over a number of years in Bangladesh (Alam et al., 1994), 23.8\% yield loss In Nepal the (Shrestha et al., 1997). Yield looses between 20 and $52 \%$ have been reported on susceptible cultivars of south Asia (Sharma and Duveillar 2004). The disease becomes severe during the grain filling stage and causes significantly yield looses and grain quality deterioration in susceptible varieties. B. sorokiniana usually induces symptoms on leafs, sheath and stem (Chand et al., 2003). However, under severe conditions it also infects spikelet's resulting in shriveled grains with black point at the embryo end of kernels. Although spot blotch has assumed a status of number one disease in the warmer parts of eastern India, More recently it has been expanded into the cooler, traditional irrigated rice-wheat production areas (Singh et al., 2008, Singh $\mathrm{R}$ and Singh VN 2007). It is generally believed that the level of resistance in high-yielding wheat genotypes is still unsatisfactory and needs to be improved significantly in warmer and humid regions of south Asia (Sharma and Duveillar 2006). Resistance to spot blotch in wheat behaves like a Quantitative trait (Joshi et al., 2004b), but until recently little has been known about its genetics and observed that wheat genotypes expressing leaf tip necrosis (LTN) in general showed less spot blotch symptoms and demonstrated a genetic association between this phenotypic marker and spot blotch resistance in a segregating population. Quantitative trait loci (QTLs) for resistance have recently been mapped in the resistance sources 'Yangmai\#6' (Kumar et al., 2009), 'Ning 8201' and 'Chirya-3' (Kumar et al., 2010).

In the past 10 years, efforts have been made to identify spot blotch resistant wheat genotypes derived from new resistance source such as synthetic wheat, including Thinopyrum curvifolium and Aegilops tauschii derivatives (Sharma et al., 2004a). Despite the realization of spot blotch as an important disease of wheat, the progress in breeding for resistance against this disease has not been satisfactory. One of the reasons for this slow progress is the lack of proper knowledge about the variability in the isolates of B. Sorokiniana. Phenotyping and genotyping study on spot blotch disease is already done and in progress at Indian Institute of Wheat and Barley Research, Karnal, Haryana (India)(Virender Singh et al., 2012, Ashish Ojha et al., 2012, Virender et al, 2015) Therefore, there is a urgent need to exploit the existing genetic variability in wheat for evolving high yielding varieties that have wide adoptability and are highly productive under a changing climatic scenario. Hence present study is concerned to identify disease resistant donor parents for their utilization in wheat breeding and controlling the disease \& ultimately provides the cheapest and easiest way of increasing the productivity.

\section{Material and Methods:-}

\section{Plant Materials and field evolution:-}

The study material comprised 100 (One hundred) Varieties, Genotypes/ germplasm or cultivars which have diverse genetic background and origin. Mostly wheat genotypes exotic to south Asia/Cimmyt and India were included in this study, because these genotypes were specially used as parents for improving spot blotch resistance. All genotype were evaluated during rabi season, wheat growing season (December to April) 2011, 2012 and 2013 under field and polyhouse at Indian Institute of Wheat and Barley Research. Karnal, Haryana and Coochbehar (West Bangal), which are identified as a hot spot for the spot blotch disease. The experimental Material was laid out following a randomized complete block design. Each line was sown in single row of $2 \mathrm{mt}$ under polyhouse and row to row and plant to plant distance was $25 \mathrm{~cm}$ and $5 \mathrm{~cm}$, respectively.

\section{Creation of artificial epiphytotic conditions in the field:-}

To promote disease build up and spread, mixture of highly susceptible genotypes was planted as a border row after 15 lines. To provide maximum disease chance of disease spread during flowering time, late sown was done. The standard agronomic practices were followed while epiphytotic condition was created in the field. Although, Coochbehar and Karnal is a good hot spot for spot blotch of wheat, experimental materials were also provided additional inoculums artificially. A pure culture of Coochbehar isolates (most aggressive isolate) of B. sorokiniana was multiplied on sorghum grains and the spore were harvested in water. A spore suspension adjusted to approximately $10^{4}$ spores/ml of water was uniformly sprayed at three different growth states (GS), viz., tilling (GS20), flag leaf emergence (GS37) and anthesis (GS65) during evening hours. The field was irrigated immediately after inoculation and total five to six irrigations were given in the entire crop period to provide a favorable environment for the development of spot blotch disease. The first irrigation was given 21 days after sowing. 


\section{Under polyhouse conditions:-}

Out of the 100 genotypes only 20 genotypes which showed field resistance, were used for under polyhouse conditions mechanically inoculated by using hand atomizer under polyhouse conditions at Directorate of Wheat Research, Karnal during rabi season 2001, 2012 \& 2013. (Table-2) Each genotype was also characterized under artificial inoculation. Each genotype sown by hill planting method consisted 3-5 seeds/hill. A pure culture of Coochbehar isolates of B. sorokiniana was multiplied on sorghum grains, and spores were harvested in water. A spore suspension of 50,000 spores/ $\mathrm{ml}$ was uniformly sprayed at the four to five leaf stage followed by a second spray after a week to build up sufficient disease pressure.

\section{Disease Assessment:-}

Assessment of Disease severity (\%) was done using double digit scale (DD, 00-99), displayed by all the leaves of each row was recorded at three different growth stages(GS), viz., GS63 (beginning of Anthesis to half complete), GS 69 (Anthesis complete) and GS 77 (late milking). The area under disease progress curve (AUDPC) based on disease severity (GS63, GS 69 and GS77) over time was estimated using the following formula (Roelfs et al., 1992)

\section{Result and Discussion:-}

One hundred wheat genotypes screened against native isolate of $B$. sorokiniana at the Directorate of Wheat Research, Karnal location on field and polyhouse showed different reactions, indicating that the genetic variability / variations for response to leaf blight among the entries scored at both environments as shown by disease score. Since high spot blotch score occurred in the experimental field and polyhouse, as shown by disease score of 89 (Sonalika and HD 2329) and 79 (HUW 234 and Raj 4015), indicating that the season and environments were compatible for disease screening and there would be low chance to susceptible genotypes to score as resistant lines. Out of these one hundred lines with 4 checks (Highly Susceptible lines) screened for resistance to leaf blight none of them were find totally immune or disease free. Out of total entries tested, 20 were highly resistant, 28 resistant, 22 moderately resistant, 15 moderately susceptible and 15 Susceptible lines (Table-1). Out of the 20 highly resistant lines category, 11 were CIMMYT lines, 05 Indigenous genetic stocks 04 Chinese lines, 01 other and 04 released Indian variety were used for as checks. The exotic lines comprised bred wheat and synthetic wheat lines from CIMMYT and China. The CIMMYT lines were Yangmai \#6, Mayoor, HRLSN-2, and 9, 13, 14, 15, 16, 22, 23 and HRLSN 24. The Chinese lines, Chirya-1, 3 and 7 also showed resistance $<13$ or 13 score. In addition of these exotic lines, 07 Indigenous genetic stocks LBRL-1, 6,12,13 and LBRL-14 lines which were established genetic stocks of NEPZ and NWPZ parts of India were also identified as highly resistant. All the 04 checks, Sonalika, HUW 234, Raj 4105 and HD 2329 were showed highly susceptible with $>79$ and 89 score. Three Thinopyrum curvifolium derivatives Chirya-3, Chirya-7 and Mayoor recorded the lowest mean disease 12 score. These lines originate from CIMMYT, Mexico and have introduced in India in 1996. Yangmai\#6 line originated from Cimmyt and Indigenous genetic stocks LBRL-1, 6, 12, 13 and LBRL14 also have a lower mean score12 under artificial epiphytotic polyhouse conditions. These all 20 lines in field natural conditions, showed highly resistant or immune with disease score $(00$ 03) for spot blotch.(Table-3) The distinct resistance in these lines identified here can be used as valuable source in wheat breeding for spot blotch infected areas in India and other countries. Most of the entries classified as resistant had score ranging 13 to 25 (28 lines). As the disease progressed from the bottom to the top of the plant, the disease area on the leaf below the flag leaf (F-1) was greater than that of on the flag leaf. There were distinct differences between the lines characterized as resistant with a score between 00-12 and 13-23/25 and moderately resistant and moderately susceptible with the score of 36 to 45 and 56 to 68, susceptible and highly susceptible with the score of 78 to 89 and up to score 89 . Twenty most resistant with four most susceptible lines (used as a Check) were selected for genetic analysis to characterize genotypic variations for resistance to spot blotch under artificial epiphytotic conditions created in polyhouse during same rabi season. The spot blotch reactions of the selected lines were category under polyhouse conditions as compared to field natural conditions (Table-2). Earlier Chaurasia et al., (1999) had reported that of 1387 wheat lines screened between 1994 and 1997, at spot blotch hot spot location and find most of the resistant lines were represented by CIMMYT materials. Low to moderate level of resistance to spot blotch in international wheat germplasm was reported by Dubin et al., (1998). Recently, Singh et al., (2014) reported a set of recombinant inbred lines were screened for spot blotch disease under natural and artificial epiphytotic polyhouse condition at three hot spot locations in India and find some resistant lines. 
Table 1:- Categorization of 100 germplasm line of wheat to their disease response to spot blotch caused by B. Sorokiniana during rabi season 2011-12, 2012-13 to 2013-14

\begin{tabular}{|c|c|c|c|c|}
\hline & & & \multicolumn{2}{|c|}{ Range of leaf area blighted (\% } \\
\hline Category & Double digit score & No of lines & $\begin{array}{l}\text { Flag leaf } \\
\text { Min-Max. }\end{array}$ & $\begin{array}{l}\text { Flag-1 leaf } \\
\text { Min to Max }\end{array}$ \\
\hline Highly resistant (HR) & $<12$ & 20 & 00 & $0-05$ \\
\hline Resistant (R) & $13-25$ & 28 & $05-10$ & $10-20$ \\
\hline Moderately resistant (MR) & $36-45$ & 22 & $10-30$ & $21-40$ \\
\hline Moderately Susceptible (MS) & $56-68$ & 15 & $21-50$ & $41-60$ \\
\hline Susceptible (S) & $78-89$ & 15 & $41-70$ & $61-80$ \\
\hline Highly Susceptible (Hs) & $>89$ & -- & $61-80$ & $81-100$ \\
\hline
\end{tabular}

Table 2:- Pedigree and Source of origin of selected 20 Genotypes/germplasm

\begin{tabular}{|c|c|c|c|c|}
\hline S.No. & $\begin{array}{c}\text { Genotype/ } \\
\text { Germplasm }\end{array}$ & Pedigree & Resistant Source & Origin Source \\
\hline 1 & CHIRYA-1 & \multirow{3}{*}{$\begin{array}{l}\text { Chinese } \quad \text { Spring/Ag.Cu//Glennson- } \\
\text { 81/3/Alondra/Pavon76/4/Ningmai-4 } \\
\text { /Olesen//Alondra/Yangmai-4 }\end{array}$} & HLB & China \\
\hline 2 & CHIRYA-3 & & HLB & China \\
\hline 3 & CHIRYA-7 & & HLB & China \\
\hline 4 & HRLSN 2 & BL1882=N1297/Oceear-7//BL1022 & HLB & CIMMYT \\
\hline 5 & HRLSN 9 & ZSH12/HLB19//NL 297 & HLB & CIMMYT \\
\hline 6 & HRLSN13 & ZSH/HLB-48//NL297 & HLB & CIMMYT \\
\hline 7 & HRLSN 14 & BL1530/BL1095 & HLB & CIMMYT \\
\hline 8 & HRLSN 15 & $(205) / 5 / \mathrm{BP}-10 * 3 / 4 /$ & HLB & CIMMYT \\
\hline 9 & HRLSN 16 & BL1910=ZSH23/HLB15//NL297 & HLB & CIMMYT \\
\hline 10 & HRLSN 22 & $\mathrm{NL}=\mathrm{AESQ}(205) / 5 / \mathrm{BR} 12 * 3 / 4$ & HLB & CIMMYT \\
\hline 11 & HRLSN 23 & NL-750 'S' & HLB & CIMMYT \\
\hline 12 & HRLSN 24 & MILLAN/SHA-7 & HLB & CIMMYT \\
\hline 13 & LBRL-1 & PBW 343/ CHIRYA-3 & HLB & India \\
\hline 14 & LBRL 6 & UP-262/CHIRYA-7 & HLB & India \\
\hline 15 & LBRL 12 & KANCHAN/NL 721 & HLB & India \\
\hline 16 & LBRL 13 & MILLAN/BH1146 & HLB & India \\
\hline 17 & LBRL14 & NW1012/YM\#6 & HLB & India \\
\hline 18 & BH 1146 & PG1//FRTR/MTA & HLB & Brazil \\
\hline 19 & YM\#6 & DAFDAFENG-1087/ZAO-5 & HLB & CIMMYT \\
\hline 20 & Mayoor & CIGM-84.295 & HLB & CIMMYT \\
\hline
\end{tabular}


Table 3:- Reaction of 20 highly resistant selected lines from field of wheat against $B$. sorokinaina under polyhouse conditions.

\begin{tabular}{|c|c|c|c|c|c|c|c|c|c|c|}
\hline & & \multicolumn{3}{|c|}{ POLYHOUSE } & & & \multicolumn{3}{|c|}{ FIELD } & \multirow{3}{*}{$\begin{array}{c}* * \text { Overall } \\
\text { Mean }\end{array}$} \\
\hline $\begin{array}{l}\text { S. } \\
\text { N. }\end{array}$ & Varieties & $\begin{array}{l}2011- \\
2012\end{array}$ & $\begin{array}{l}2012- \\
2013\end{array}$ & $\begin{array}{l}2013- \\
2014\end{array}$ & \multirow[t]{2}{*}{$\begin{array}{c}\text { **Over all } \\
\text { Mean }\end{array}$} & Varieties & $\begin{array}{l}2011- \\
2012\end{array}$ & $\begin{array}{l}2012- \\
2013\end{array}$ & $\begin{array}{l}2013- \\
2014\end{array}$ & \\
\hline & & $\begin{array}{c}* \text { Mean } \\
\text { HLB }\end{array}$ & $\begin{array}{l}\text { *Mean } \\
\text { HLB }\end{array}$ & $\begin{array}{l}\text { *Mean } \\
\text { HLB }\end{array}$ & & & $\begin{array}{l}\text { *Mean } \\
\text { HLB }\end{array}$ & $\begin{array}{c}{ }^{*} \text { Mean } \\
\text { HLB }\end{array}$ & $\begin{array}{c}\text { *Mean } \\
\text { HLB }\end{array}$ & \\
\hline 1 & CHIRIYA-1 & 13 & 13 & 12 & 13 & CHIRYA-1 & 01 & 01 & 01 & 01 \\
\hline 2 & CHIRYA-3 & 13 & 12 & 12 & 12 & CHIRYA-3 & 01 & 02 & 01 & 01 \\
\hline $\mathbf{3}$ & CHIRYA-7 & 12 & 12 & 12 & 12 & CHIRYA-7 & 01 & 02 & 01 & 01 \\
\hline 4 & HRLSN 2 & 12 & 12 & 12 & 12 & HRLSN 2 & 01 & 01 & 01 & 01 \\
\hline 5 & HRLSN 9 & 13 & 13 & 13 & 13 & HRLSN 9 & 03 & 03 & 02 & 03 \\
\hline 6 & HRLSN13 & 12 & 12 & 12 & 12 & HRLSN13 & 02 & 03 & 02 & 02 \\
\hline 7 & HRLSN 14 & 13 & 13 & 13 & 13 & HRLSN 14 & 02 & 03 & 02 & 02 \\
\hline 8 & HRLSN 15 & 12 & 12 & 12 & 12 & HRLSN 15 & 02 & 01 & 01 & 01 \\
\hline 9 & HRLSN 16 & 13 & 13 & 12 & 13 & HRLSN 16 & 03 & 03 & 02 & 03 \\
\hline 10 & HRLSN 22 & 12 & 12 & 12 & 12 & HRLSN 22 & 02 & 01 & 01 & 01 \\
\hline 11 & HRLSN 23 & 13 & 13 & 12 & 13 & HRLSN 23 & 02 & 03 & 02 & 02 \\
\hline 12 & HRLSN 24 & 12 & 12 & 13 & 12 & HRLSN 24 & 02 & 02 & 02 & 02 \\
\hline 13 & LBRL-1 & 12 & 12 & 12 & 12 & LBRL-1 & 01 & 02 & 02 & 02 \\
\hline 14 & LBRL 6 & 12 & 12 & 12 & 12 & LBRL 6 & 02 & 01 & 02 & 02 \\
\hline 15 & LBRL 12 & 12 & 12 & 12 & 12 & LBRL 12 & 02 & 01 & 02 & 02 \\
\hline 16 & LBRL 13 & 13 & 13 & 13 & 13 & LBRL 13 & 02 & 02 & 03 & 02 \\
\hline 17 & LBRL14 & 12 & 12 & 12 & 12 & LBRL14 & 03 & 03 & 03 & 03 \\
\hline 18 & BH1146 & 12 & 12 & 12 & 12 & BH1146 & 02 & 02 & 02 & 02 \\
\hline 19 & YM\#6 & 12 & 12 & 12 & 12 & YM\#6 & 03 & 02 & 02 & 02 \\
\hline 20 & Mayoor & 12 & 13 & 13 & 13 & Mayoor & 02 & 02 & 02 & 02 \\
\hline
\end{tabular}

$*=$ Mean value of replicated Trials of each year $* *=$ Overall mean values of three years replicated mean value

\section{References:-}

1. Sharma, R.C. and Duveiller, E. (2004): Effect of Helminthosporium leaf blight on performance of timely and late-seeded wheat under optimal and stresses levels of soil fertility and moisture. Field Crops Research., 89: 205-218.

2. Sharma, R. C., Duveiller, E., Ahmed, F., Arun, B., Bhandari, D., Bhatta, M. R., Chand, R., Chaurasiya, P. C. P., Gharti, D. B., Hossain, M.H., Joshi, A.K., Mahto, B.N., Malaker, P.K., Reza, M.A., Rahman, M., Samad, M.A., Shaheed, M.A., Siddique, A.B., Singh, A.K., Singh, K.P., Singh, R.N., Singh, S.P. (2004a): Helminthosporium leaf blight resistance and agronomic performance of wheat genotypes across warm regions of South Asia. Plant Breeding., 123:520-524.

3. Chaurasia, S., Joshi, A. K., Dhari, R. and Chand, R. (1999): Resistance to foliar blight of wheat: A search on Genetic Research. Crop Evolution., 46:469-475.

4. Roelfs, A. P., Singh, R.P. and Saari, E. E. (1992): Rust Disease of wheat: Concepts and methods of disease Management. CIMMYT, Mexico, USA, pp.37-38.

5. Velu, G. and Singh, R.P. (2013): Phenotyping of wheat breeding, In: S.K. Panguluri and A.A. Kumar (eds), Phenotyping for Plant Breeding: Springer New York, pp.41-71.

6. Joshi, A. K., Ortiz-ferrara, G., Crossa, J., Singh, G., Alvarado, G., Bhatta, M. R., Duveillar, E., Sharma, R. C., Pandit, D. B., Siddique, A. B., Das, S.Y., Sharma, R. N. and Chand, R. (2007): Associations of environments in south Asia based on spot blotch disease of wheat caused by Cochliobolus sativus. Crop Science., 47: 10711081.

7. Singh, V. and Singh, V. N. (2007): Management of spot blotch of wheat (Triticum aestivum) caused by Bipolaris sorokiniana. Indian Journal of Agriculture Science., 77: 323-326.

8. Chand, R., Pandey, S. P., Singh, H. V., Kumar, S. and Joshi, A. K. (2003): Variability and its probable cause in natural populations of spot blotch pathogen Bipolaris sorokiniana of wheat (T. aestivum L.) in india. Journal Plant Disease Protection., 110: 27-35. 
9. Chatrath, R., Mishra, B., Ferrara, G. O., Singh, S. K., and Joshi, A. K. (2007): Challenges to wheat production in South Asia. Euphytica., 157:447-456.

10. Kumar, U., Joshi, A. K., Kumar, S., Chand, R. and Roder, M. S. (2009): Mapping of resistance to spot blotch disease caused by Bipolaris sorokiniana in spring wheats. Theoretical and Applied Genetics., 118:783-792.

11. Joshi, A. K., Kumari, M., Singh, V. P., Reddy, C. M., Kumar, S., Rane, J. and Chand, R. (2007a): Stay green trait: variation, inheritance and its association with spot blotch resistance in spring wheat (Triticum aestivum L.). Euphytica.,153:59-71.

12. Joshi, A. K., Kumar, S., Ferrara, O. and Chand, R. (2004b): Inheritance of resistance to spot blotch caused by Bipolaris sorokiniana in spring wheat. Plant Breeding., 123:213-219.

13. Chowdhury, A. K., Singh, G., B, S. Tyagi., Ojha, A., Dhar, T. and Bhattacharya, P. M. (2013): Spot blotch disease of wheat - a new thrust area for sustaining productivity. Journal of Wheat Research., 5:1-11.

14. Singh, G., Tyagi, B. S., Singh, G. P., Chatrath, R., Singh, D. P. and Jag, Shoran. (2008): Genetic analysis and association of spot blotch resistance caused by Bipolaris sorokiniana with morphological and yield attributes in bread wheat (Triticum aestivum). Indian Journal of Agricultural Sciences. 78:957-61.

15. Kumar, U., Joshi, A. K., Kumar, S., Chand, R. and Roder, M. S. (2010): Quantitative trait loci for resistance to spot blotch caused by Bipolaris sorokiniana in wheat (T.aestivum L.) lines 'Ning 8201' and 'Chirya 3'. Molecular Breeding., 26:477-491.

16. Saari, E. E. and Prescot, J. M. (1975). A scale for appraising the foliar intensity of wheat disease. Plant Disease Reporter., 59: 377-380.

17. Satvinder, K., Nanda, G. S., Navneet, G., Kaur, S. and Ghuman, N. (2002): Status of seed health and facultative foliar pathogens of wheat in Punjab from 1992-1999. Journal of Research, Punjab Agricultural University. 39(1):28-34

18. Alam, K. B., Shaheed, M. A., Ahmed, A. U. and Malakar, P. K. (1994). Bipolaris leaf blight (spot blotch) of wheat in Bangladesh. In: D.A. Saunders and G.P. Hettel (Eds.): Wheat in Heat Stressed Environments: Irrigated, Dry areas and Rice-Wheat Farming Systems., pp.339-342. Mexico, D. F. CIMMYT.

19. Shrestha, K. L., Timila, R. D., Mahto, B. N. And Bimb, H. P. (1997): Disease incidence and yield loss due to foliar blight of wheat in Nepal. (Eds.): E. Duviller, H.J. Dubin, J. Reeves and A. McNab. Helminthosporium blight of wheat: spot blotch and tan spot. Proc. Int. Workshop held at CIMMYT El Batan, Mexico. 9-14 Feb. 1997. pp:67-72.

20. Singh, G., Sheoran, S., Chowdhury, A. K., Tyagi, B. S., Bhattacharya, P. M., Singh, V., Ojha, A., Rajita. and Sharma, Indu. (2014): Phenotypic and marker aided identification of donors for spot blotch resistance in wheat. Journal of Wheat Research., 6:98-100.

21. Ojha, A., Singh, G., Singh, C., Tyagi, B. S., Singh, V. and Sharma, Indu. (2012): Potential donors for improving host resistance against spot blotch disease in wheat. International conference on Sustainable for food and Livelihood Security, Nov. 27-29. Crop Improvement, Punjab Agriculture University., pp.897-898.

22. Singh, V., Sheoran, S., Singh, G., Chowdhury, A .K. , Ojha, A., Choudhary, R., Rajita, Chaudhury, A. K. and Indu, Sharma. (2012): Molecular Markers Associated with spot blotch resistance in Wheat. International conference on Sustainable for food and Livelihood Security, Nov. 27-29. Crop Improvement, Punjab Agriculture University., pp.451-452

23. Singh, V., Singh, G., Chaudhury, A. K., Chowdhury, A. K., Tyagi, B. S., Rajita, Ritu, Ojha, A. and Sonia, Sheoran. (2015): Phenotypic and Genotypic Evaluation of RILs for Spot Blotch Resistance in Wheat. International Journal of Tropical Agriculture., 33:1799-1804.

24. Dubin, H. J. (1998): Results of the south Asia regional Helminthosporium leaf blight and yield experiment, 1993-94. In: Duveillar, E., Dubin, H.J., Reeves, J., McNab, A. (eds) Helminthosporium blights of wheat: spot blotch and tan spot. CIMMYT, Mexico., pp. 182-187. 